\title{
La poesía kitsch como instrumento del poder en el siglo XVII
}

\author{
Pedro Aguilar SERrano \\ Campus de Guadalajara \\ pedroaguilarserrano@gmail.com
}

\begin{abstract}
Resumen:
Muchos de los poemas que formaban parte de los cancioneros y volúmenes de poesías varias que circulaban durante el Barroco eran productos kitsch elaborados para satisfacer la demanda de información y cultura de una naciente sociedad de masas. Obras de consumo masivo creadas, no sólo para entretener sino para transportar un mensaje que, desde el poder, llegase al mayor número posible de receptores. Todo ello en un contexto, el siglo XVII, en el que cancioneros, pliegos de cordel y romanceros cubrían la ausencia de los medios de comunicación de masas.
\end{abstract}

Palabras clave: Kitsch; ideología; poder; mensaje; comunicación; masas

\section{Poetry kitsch, instrument of power in the $17 \mathrm{TH}$ century}

\begin{abstract}
:
Many of the poems that were part of the song books and volumes of poetry, several circulating during the Baroque were kitsch products to meet the demand for information and culture of an emerging mass society. Works of mass consumption created, not only to entertain but to convey a message that, since power, reaching the largest possible number of receivers. All this in a context, the 17TH century, in which songbooks and sheets of string and novelists covered the absence of mass media.
\end{abstract}

Key Words: Kitsch; ideology; power; message; communication; masses

\section{Referencia normalizada:}

Aguilar Serrano, P. (2014): La poesía kitsch como instrumento del poder en el siglo XVII. Historia y Comunicación Social. Vol. 19. Núm. Especial Marzo. Págs. 689-701.

Sumario: 1. Introducción. 2. La socialización de la cultura, el kitsch. 3. Cultura de masas. 4. Poemas burlescos, sustento literario del kitsch. 5. Gusto popular por la dificultad. 6. Conclusión. 7. Bibliografía.

\section{Introducción}

Cuando se habla de kitsch en comunicación y literatura, es obligado fijar la definición de un término que no cuenta con la unanimidad de los estudiosos en sus acepciones. Nosotros nos ceñiremos en este trabajo a la que sugiere Bárbara Pregelj (1999): 
"Un cierto tipo de literatura que por razones estéticas, funcionales o masivas ha sido devaluada". Nos parece una definición clara, completa y atemporal.

A este tipo de manifestación literaria, el kitsch, en Alemania se le conoce con el nombre de Trivialliteratur. En español se usan términos como literatura popular, subliteratura, literatura de masas, literatura de consumo, vocablos todos que recogen sólo parcialmente el sentido de este tipo de obras. La literatura kitsch siempre ha sido entendida como inferior a la literatura canonizada, con un escaso valor literario, no muy exigente y asequible a todos los receptores. Ahora bien, dentro de obras literarias canonizadas puedan aparecer elementos propios del kitsch, como pueden ser ciertos personajes, ciertas situaciones o incluso ciertos diálogos en las grandes obras teatrales del siglo de Oro (La vida es sueño, por ejemplo), entendidos como guiños al gran público.

Buena parte de la crítica literaria sitúa el origen del kitsch en el siglo XVIII, sin embargo cada vez son más los que defienden que a lo largo del siglo XVII se produce ya un cambio de gusto radical, un divorcio entre el gusto literario popular y el gusto de las elites. Surge entonces, no sólo un cambio de apetencia, sino un nuevo receptor de la literatura, una masa de lectores y oidores que antes no era muy tenida en cuenta y que ya en los primeros años del XVII forma un "contexto colectivo" (García de Enterría en Pregelj, 1999) y a cuyo gusto se pliegan los escritores y los editores. En ese sentido, la literatura de cordel, de la que se nutren los cancioneros de la época, es un fiel reflejo de esta realidad.

\section{La socialización de la cultura}

Todo sistema cultural no deja de ser un instrumento de integración y en cierto modo una herramienta para dominar las tensiones internas que amenazan a la sociedad. En este sentido, la cultura barroca fue una cultura para reducir no sólo la inquietud religiosa, como asegura Maravall (1980), sino toda la inseguridad producida por los cambios que se suceden en Occidente en el siglo XVII. Uno de los cambios más importantes que se produjeron en la nueva sociedad barroca fue la transformación de hábitos, costumbres y gustos de sus miembros producida por la concentración de población en las ciudades. Tuvieron lugar en aquella época una serie de alteraciones demográficas acompañadas de cambios en las relaciones de los grupos entre sí, cambios en las creencias y en los modos de vida, que produjeron obligatoriamente cambios culturales. Las exigencias de una nueva situación social en el Barroco dieron lugar a una cultura (arte, literatura, juegos sociales, etc..) que se basaba en las nuevas relaciones de mercado y de posición de la población consumidora, y necesitaba de nuevos productos comerciales de todo tipo, incluidos los culturales. Productos que en el caso de la literatura se vieron favorecidos por el abaratamiento de los costes de impresión. 
En el Barroco son muy numerosos los productos que en cada una de las modalidades artísticas se elaboran porque la demanda es mucha y variada. Las condiciones son pues las idóneas para que junto a una literatura elitista, hermética y canonizada (Pregelj 1999), difícil en muchos casos, dentro de ese gusto por el artífico y la ocultación que tanto fascinaba en la época; se produzca otra literatura popular, masiva y no canonizada, que en ocasiones podría identificarse con ese tipo de literatura que "por razones estéticas, funcionales o masivas ha sido devaluada", o sea el kitsch.

Una cultura vulgar, caracterizada por el establecimiento de tipos, con repetición estandarizada de géneros, presentando una tendencia al conservadurismo social y respondiendo a un consumo manipulado. (Maravall 1996).

La cultura kitsch se caracteriza, hoy como en el siglo XVII, por su universalidad respecto de una supuesta y autodenominada cultura de elite y va siempre referida a otro nivel cultural que se estima como superior. Es más, el kitsch se asocia desde el principio a la cultura de masas a pesar de que algunas equiparaciones de diccionario lo aproximan a lo cursi (Bueno 1997).

Dentro de esta cultura kitsch encajan perfectamente las comedias que, por cientos, se representaban cada año en los corrales y en los teatros de los pueblos y ciudades españolas, las novelas y relatos cortos de caballería o de temática pastoril y sentimental, y también aquellos volúmenes de poesías varias o cancioneros repletos de romances de ciego, villancicos, coplas y demás estrofas rimadas que, como el manuscrito RAE RM 6212, obra inédita en la que nos vamos a centrar en este trabajo, está formado por un ramillete de poemas de muy variada temática en el que predominan obras de baja calidad, composiciones que abordan aquellos temas sobre los que se hablaba en los foros y mentideros de la época, en definitiva, poesía de consumo rápido.

La pluralidad de mensajes, de sistemas de representación, de divulgación, de maneras de entender un mismo suceso están presentes en estos cancioneros, verdadero mosaico variopinto de la realidad. Hay que tener en cuenta que en el siglo XVII no había medios de comunicación de masas, tal y como ahora los entendemos, no había radio ni televisión, ni siquiera periódicos, pero sí había un sustrato social masivo que demandaba información, productos culturales y de entretenimiento. En esa realidad, las representaciones teatrales, los pliegos, los romances de ciego o los poemas recogidos en cancioneros, satisfacían esa demanda y eran herramientas comunicativas muy golosas en manos de los poderes fácticos.

Todo lo propio al Barroco surge de las necesidades de la manipulación de opiniones y sentimientos sobre amplios públicos. Es fácil comprender que tales medios (pintura a granel, libros, canciones, libelos, carteles, representaciones teatrales...), en su naturaleza y posibilidades de influir, estén siempre, ayer como hoy, en relativa dependencia de la estructura de la propiedad y de las formas de gestión de la misma (...) El hecho de que los libros se envíen a carretadas desde Lyon y otras ciudades europeas en verdaderas recuas, como hiperbólicamente dice Saavedra Fajardo, revela un hacinamiento de población y una industria cultural a su servicio. (Maravall 1996, págs. 184-185). 
La sociedad barroca, como primera sociedad de masas, estaba inundada de productos kitsch en todas las facetas del arte, obras que no corrieron la misma suerte en épocas posteriores. En la literatura muchos de estos géneros fueron rechazados posteriormente, sobre todo en el siglo XVIII y buena parte del XIX.

\section{Cultura de masas}

En la segunda mitad del XVII hay un importante número de personas que demanda cultura como una necesidad vital y social, alejada de las meras necesidades de subsistencia, ya lo hemos insinuado. No se trata de una elite minoritaria, de un reducido número de personas formadas y cultivadas, sino de una mayoría social importante. Esta petición cada vez más extensa es satisfecha con la producción masiva y rápida de productos culturales, lo que obligatoriamente conlleva una disminución de la calidad de dichos productos. En el caso de la poesía son numerosos los rasgos que caracterizan esta manera de hacer literatura: la repetición de temas, el uso de tópicos y estereotipos repetidos hasta la saciedad o el escaso cuidado de los aspectos formales (lo inacabado, el descuido, lo difícil), entre otros.

El vulgo pagaba y por tanto exigía aquel producto que le gustaba. El autor cobraba y creaba aquello que el público pedía. Este detalle es una novedad en el siglo XVII con respecto a épocas anteriores, un nuevo modo de concebir la creación artística que afectó no sólo a la comedia sino a todo el sistema de la literatura, autores y obras, que poco a poco fueron convirtiéndose en objeto de pura mercancía, y por supuesto también estuvo presente en el resto de manifestaciones artísticas. Este proceso que se inicia en la literatura española del siglo XVII es fácil de observar por lo menos en tres géneros literarios: poesía, teatro y novela. (Pereglj 1999).

Muchos críticos sostienen que esa masiva producción kitsch fue una de las causas de que durante decenas de años se identificara popularmente el estilo Barroco con un estilo de mal gusto. Esta aseveración no es justa si se estudia el fenómeno en toda su magnitud, pero algo hay de cierto. El kitsch se caracteriza por imitar con "material y herramientas" inferiores un modelo de mayor calidad. Todo aquel que produce cultura kitsch busca tocar la fibra sensible del espectador, emocionar, alcanzar los sentimientos más someros para obtener la respuesta deseada, en definitiva ganarse al receptor con recursos fáciles pero efectivos. El que crea este producto defiende también unos intereses que pueden ser individuales o de grupo, casi siempre monetarios o ideológicos, o incluso ambos a la vez. En una época en que, como ahora, "la opinión movía el mundo" (Lancina en Maravall, 1996), se manipulan las opiniones que vierte la obra, siempre al servicio de determinados fines. Como asegura Ludwig Giesz en su obra Fenomenología del kitsch (1960), quienes producen hoy el kitsch no son mentes ingenuas, sino astutos sicólogos de masas, como sin duda lo fueron, a su manera, los hombres del XVII.

Las organizaciones de las grandes empresas cinematográficas, de radiodifusión, de revistas ilustradas, etc.. económicamente poderosas y con un objetivo determi- 
nado, no sienten realmente ningún gusto por el kitsch e incluso fomentan con espíritu de mecenas lo que ellos consideran arte. Pero se dedican al negocio de la producción de kitsch. Tanto los compositores y letristas de música ligera, como los guionistas, editores y autores de literatura de consumo, grafistas, fotógrafos y expertos en radiodifusión, trabajan de forma más o menos cínica, premeditada, técnica y psicológicamente desapasionada, rutinaria. A diferencia de la masa, ellos saben que el kitsch no es arte. (Giesz 1960, págs. 94-95)

Aunque con otras herramientas y otros medios a su alcance, los productores de kitsch del Barroco tienen la misma actitud y obedecen a los mismos intereses que los del siglo XXI. Utilizan los resortes del kitsch, como acertadamente apunta Maravall, para configurar tipos, formar mentalidades y agrupar masas ideológicamente.

Así se tendrán individuos extrarracionalmente fundidos en sus opiniones, al servicio de la organización social, política y económica de la época; esto es, de los intereses de la monarquía y del grupo de los señores. Aplaudir a Lope en su Fuenteovejuna era estar junto a la monarquía, con sus vasallos, sus libres y pecheros. Aplaudir a Quevedo era también lo mismo, aunque pudiera surgir el caso de una discrepancia, mayor o menor, entre los que formaban el grupo dirigiente. (...) No porque se propusiera en el texto o en el lienzo o en el escenario la adhesión a un sistema, sino porque se ayudaba la mentalidad que habría de servir a ello de base. La industria cultural del XVII, los miles y miles de cuadros y de sonetos, de obras teatrales, pero también de prendas de vestir, de libelos y pasquines (con los que se formaban los cancioneros), de modos y ocasiones de conversar, pasear, distraerse, etc.., planta su manipulación desde los centros en que se imponía el gusto. (Maravall 1996, pág. 198)

Si había que mandar mensajes, la reiteración era una herramienta imprescindible en los diferentes lenguajes comunicativos, pero también el sentimentalismo, la pasión o las soluciones fáciles conocidas, si se pretendía hacer partícipe al receptor, incluso la pobreza literaria, es decir, el sustento de lo que conocemos como kitsch.

Los cancioneros, que como el que nos ocupa (RAE RM 6212), son fruto de un coleccionista de poemas que pica de flor en flor y tan pronto recoge un poema de Cervantes presente en las grandes antologías de la época (en pliegos de cordel y cancioneros de venta al público se usaba el nombre de los poetas famosos como reclamo para incitar a la venta) como una cancioncilla de patio de colegio. Es un fruto más de ese afán por consumir cultura, y a la vez de esa necesidad por recoger en un mismo volumen todo aquello que se identifica con su manera de pensar y de ver el mundo. El recolector aspira, en definitiva, a completar una obra que aunque nada creativa, según los cánones actuales, sí lo es bajo el prisma del XVII.

\section{Poemas burlescos, sustento literario del Kitsch}

Debido a su enorme aceptación social, los poemas satíricos y burlescos son los que con mayor frecuencia han sido utilizados por los creadores de subcultura literaria. El chiste fácil, las referencias escatológicas, las escenas confusas, la incidencia en 
el defecto físico de tal o cual persona, son herramientas de fácil manejo y por consiguiente campo abonado para el kitsch.

En el cancionero RAE RM 6212 que nos sirve para argumentar nuestro trabajo, la mujer y la poesía picaril (poemas de ataque y respuesta) son el blanco de la mayor parte de los poemas satíricos. Pero también tienen su espacio los casos de corrupción de algunos políticos, la impotencia de un varón, la Armada Invencible, los clérigos, los sastres y hasta un supuesto martirio. Son todos ellos poemas de burla que han adquirido numerosos nombres a lo largo de los siglos (de mofa, jocosos, provocantes a risa, de maldecir...) pero que los analistas han acabado encuadrándolos formalmente como poemas satíricos y burlescos, herederos directos de aquellos dezires "lúdicos" que poblaban los cancioneros del cuatrocientos y del quinientos:

\author{
Enfermó Miguel Durán \\ de beber tinajas llenas, \\ sin potajes ni sin pan: \\ por el barbero le van \\ que le sangre de las venas. \\ Con sus malos apetitos, \\ hállanle las venas duras \\ cuescos d'uvas y mosquitos \\ salen por las sangraduras. (Antón de Montoro en Poesía Cancioneril, 1984, pág. \\ 249)
}

Como vemos en este poema, este subgénero no posee carácter didáctico alguno, entre otras razones porque el público al que iba dirigido, círculos sociales muy reducidos y formados, no exigía ni pretendía ningún tipo de moralización sino simplemente divertirse.

Pero junto a los calificados como lúdicos, estaban también los dezires de invectiva, unos poemas que se alejaban del protocolo y la lisonja cortesana, "y cuyo objeto era el ataque virulento de modo crítico o burlesco dirigido contra individuos". (Ortega, 2010). En los dos casos, tanto en los que podemos llamar poemas sin maldad (lúdicos) como en los que tienen cierta dosis de inquina personal o colectiva (de invectiva), la búsqueda y consecución de la risa del receptor era lo que más preocupaba al poeta, mucho más que los aspectos didácticos que no serán prioritarios en esta poesía hasta los albores del siglo XVII. Despertar ese reflejo casi histérico que era la risa, era obligatorio para el poeta, pues era sinónimo de éxito a la hora de entretener al respetable, y lo será también cuando la intención del poeta vaya más allá. La recepción del mensaje es mucho más eficaz si lleva aparejada la risa, y, no nos olvidemos, en el Barroco, por muy pueril que sea el poema, siempre esconde una intención.

Los dezires de invectiva, de ataque directo contra individuos, provocan una risa hiriente y excluyente de la víctima, mientras que los dezires gayosos o lúdicos sólo pretenden arrancar una carcajada, haciendo cómplice al receptor. En ocasiones, el poeta publica sus propios infortunios, sus avatares vitales, para hacer reír a los demás y hacerles olvidar sus pesares. En esa línea estaría el poema 1 del RAE RM 6212: 
Discurso y vida de un soldado rompido

A mi me llaman Joan del Albarado, soi pobre i rico y uso de soldado

Nazí en el Nilo en medio de la arena, criome allá en la India una amazona, un mes estuve en la torrida zona (...)

Quando me vide hecho caballero al Betis vine i enbarqueme en Coria, cargué una nao de cardo y zanahoria, vendila en Flandes y jugué el dinero.

Allí asenté por mozo de un plaiero, las mulas le vendí, volvíme a España, híceme mercader de miel de caña $\mathrm{y}$ en siete años ahorré un ducado a mi me llaman Joan de Alvarado soi pobre i rico y uso de soldado. (Poema 1. RAE RM 6212)

El poeta-soldado rompido (que va de tropiezo en tropiezo), protagonista del poema, da cuenta en primera persona de sus desgracias en una extensa narración plagada de disparates y mentiras. Se convierte en bufón vapuleado para vapulear al otro. Desde ese momento, la capacidad de reírse de sí mismo le permite insensibilizarse contra la risa del otro (liberación del sujeto) y divertir al destinatario (alivio del otro), al mismo tiempo que consigue la complicidad del receptor, incluso su indulgencia si acaso se burlase de él o del grupo del que forma parte. Si, por el contrario, poeta y receptor se mofan de un tercero, surge entonces una risa de complicidad que sin duda es un remedio muy eficaz para el alma del otro, del receptor (Ortega 2010), pero se aleja de alguna manera de la esencia "ingenua" del kitsch. Eso sí, sin olvidar que ya en el Barroco, nada es ingenuo al cien por cien.

No es menos cierto que entre el poema 19 de nuestro cancionero, en el que se critican los excesos de un ministro del Rey, Pedro Franqueza:

En el alma me ha pesado de veros presos, señor, y según por lo que dicen no sé si tienen razón.

Si es por mandado del rei, a fe que fue compasión, pues siendo vos la Franqueza por codicioso os prendió.

El peso de vuestra hacienda, me dicen os derribó, ya no bolaréis con pluma pues no os dejarán cañón (...)

Culpan os por buen cristiano, téngolo por sin razón, 
pues viendo los fariseos, la cruz escondiste vos.

Porque la hipocresía es el pecado maior, en la parte más secreta pusiste la devoción. (Poema 19. RAE RM 6212)

Y el que proponemos a continuación (poema 80), donde se parodia la postura de una fregona, hay una diferencia de intención, más allá de la calidad literaria.

Rodeada de platos y escudillas y en la mugrienta mano el estropajo, sudando grasa con el gran trabajo de no poder estar sino en cuclillas.

Bañadas de agua sucia las faldillas, metido entre las piernas el tornajo, pegado con las ancas el çancajo, meneando a la par culo y rodillas.

Anoche vide estar a mi morena cuando al son de los platos yo llegaba, no poco alegre de hallarla sola y al decirme vengáis en ora buena, como aquella postura le ayudaba, soltásele una pluma de la cola. (Poema 80 RAE RM 6212)

Con una poesía no carente de cierto ingenio, el autor del poema 80 del RAE RM 6212 busca la risa fácil poniendo a la mujer en una postura y una situación grotescas, sin el más mínimo pudor, para después rematar el poema con un efecto de clown, una ventosidad que sólo pretende la carcajada del receptor. Un producto kitsch que nos da información sobre el baremo de los gustos populares de la época.

Dentro de los dezires, era muy frecuente el ataque contra las mujeres, en una clara inversión paródica de los poemas laudatorios destinados a la dama, propios del amor cortés, en los que ella aparece siempre "subida en un pedestal". Una copia deformada de unos patrones clásicos, al más puro estilo kitsch. Los maldezidores son los encargados de bajar a la mujer al suelo y presentarla ante el pueblo de carne y hueso, en sus más ínfimas acciones a veces, lo que provoca los instintos más bajos del varón. En otras, se la muestra realizando una parodia física con un fuerte contenido escatológico. Sirvan de ejemplo estos versos extraídos del Cancionero de Baena (siglo XV):

Señora, flor de madroño yo querría sin sospecho tener mi carajo arrecho bien metido en vuestro coño.

Por ser señor de Logroño non deseo otro provecho 
sin poder coño estrecho

en estío o en otoño.

Son muchos los estudiosos que aseguran que en la literatura popular "el pleito feminista lo gana la poesía o la prosa misógina" (García de Enterría, 1973, pág. 268). La tradición es demasiado antigua y arraigada como para conseguir que en un medio conservador, como es el del pueblo, desaparezca esa visión dura y agria sobre el papel de la mujer. Vaya otro ejemplo de esa misoginia, tan manoseada por los autores de subcultura, el poema 16 del RAE RM 6212 dedicado a una dama flaca y amarilla:

Anjel almizagado que al tudesco brindas sus entresacos y entresecos, filis de nezios, discreción con Ecos, espíritu sin carne picaresco.

Tentaciones de Baco a lo bridesco, araña vil compuesta de embelecos, negra con solimán, fantasma en cueros, cuerpo pintado al olio, cara al fresco.

Toiana Elena, que reliquias solas eres de lo que fuiste, no te alteres que tu belleza y flor se a descubierto.

Abajo la bandera que enarbolas, que un poeta mui tuyo dice que eres dura en el trato y blanda en el concierto. (Poema 16. RAE RM 6212)

En el Barroco, los artistas aspiran con sus obras a obtener el asombro, la sorpresa y la maravilla del público, en lo que sería un claro antecedente de la psicagogía de la atención, una antesala de los lenguajes y tecnologías audiovisuales de hoy en día. No hay manera más eficaz para que un mensaje cale en el público que anclado al efecto sorprendente, del que no se escapa la risa. Y si no hay mensajes, ¿qué mejor que la sucesión de sucesos asombrosos para mantener entretenido al respetable?

El destinatario de la publicidad moderna será entendido cada vez más como un lector que reacciona a estímulos y cuyas respuestas son susceptibles de ser codificadas y manejadas como variables, antes que como un intérprete que lleva a cabo procesos de exégesis racional (...) ya antes de la psicologización ilustrada, la cultura barroca desarrolló esta orientación estratégica de la práctica comunicativa, tal como explica Vilaltella: en el Barroco el análisis del acto persuasivo incluye la atención a las disposiciones psicológicas del receptor y, por tanto, una teoría de los afectos. Aún más (y esta observación me parece de una extraordinaria importancia), el sujeto popular aparecerá en el horizonte cultural precisamente porque los emisores del acto persuasivo han de tomar en cuenta estratégicamente las necesidades y los sentimientos del receptor. (Abril 2003, pág.95).

La sociedad barroca, acuciada por una crisis severa, necesitaba y buscaba el esparcimiento, la diversión. El efecto final escatológico del Soneto a una fregona es un claro ejemplo. 


\section{Gusto popular por la dificultad}

Aunque le pueblo no podía participar de las formas poéticas más elevadas, si las conocía y gustaba de ver impreso en pliegos y cancioneros esas formas propias de la cultura elitista, incluso los editores usaban el nombre de los poetas reconocidos por los intelectuales de la época para vender más ejemplares. El pueblo gustaba de lo difícil, aunque no entendiese gran cosa.

Detengámonos para terminar en otro dogma de fe, el de la encarnación del Hijo de Dios, tema complejo de entender y que por consiguiente se convierte rápidamente en un tema a explotar por los creadores de kitsch para conseguir mandar al vulgo el mensaje lo más limpio posible de ataduras cultistas y disquisiciones filosóficas, aunque sin perder el atractivo de la dificultad, recurso eficaz que tanto gustaba a los hombres y mujeres del Barroco, fuesen del estrato social e intelectual que fuesen.

Fijémonos en esta coplilla:

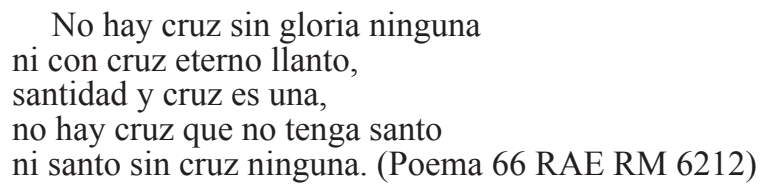

Es casi un trabalenguas, carece de sencillez expositiva, pero se aproxima en la forma a los juegos de palabras que gozaban de una gran aceptación popular. Ahora bien, por muy inconsistente que nos parezca, lleva implícito un claro mensaje. Ya hemos dicho que todo lo relacionado con la humanización del Hijo de Dios, o viceversa, con el carácter de Jesús como deidad, dogma cuestionado por los protestantes, era introducido hasta la saciedad en poemas de todo tipo, para que nadie se apartase del camino trazado por la Iglesia católica, aunque para ello hubiera que emplear burdos aparatos de artificio que en su juego encerraban alguna contradicción, con el único sentido de llamar la atención. En este caso se juega con el doble sentido de la palabra cruz, popularmente admitida como sufrimiento, carga y peso que todos llevamos encima en nuestro acontecer diario, principalmente el laboral, pero también en lo referido a la convivencia con nuestros semejantes o incluso al padecimiento de una enfermedad; y el significado religioso de la cruz como símbolo de la encarnación del Hijo de Dios y de la mortificación que hizo para salvar a la humanidad. El autor usa incluso la paradoja como herramienta para acentuar el doble significado, la complejidad dentro de la sencillez.

Lo que es indudable es que la paradoja no está lejos de la esencia católica. El cristianismo es en sí mismo una religión fundada en una paradoja: el Dios que es hombre, y que se complementa con otras paradojas más como que la Virgen es madre y la Trinidad es una.

Dentro de este maridaje entre la dificultad y el kitsch no podemos obviar las incursiones en este terreno de autores de primera fila como Lope y Góngora, o Quevedo, como podemos comprobar en este poema, en el que se aborda un complejo asunto 
metafísico como es el paso del tiempo, de una manera más que asequible para todo tipo de receptor:

La vida empieza en lágrimas y caca, luego viene la mu, con mama y coco, síguense las viruelas, baba y moco, y luego llega el trompo y la matraca. En creciendo, la amiga y la sonsaca: con ella embiste el apetito loco; en subiendo a mancebo, todo es poco, y después la intención peca en bellaca.

Llega a ser hombre, y todo lo trabuca; soltero sigue todo perendeca; casado se convierte en mala cuca.

Viejo encanece, arrúgase y se seca;

llega la muerte, y todo lo bazuca, y lo que deja paga, y lo que peca. (Quevedo 1981, pág. 561)

En la cultura barroca hay dos maneras de entender metafóricamente el tiempo: una lineal (comienzo y final de todo ser vivo) y otra cíclica (estaciones del año, por ejemplo). Las dos juntas sirven incluso hoy en día para dar cuenta de la experiencia personal que tenemos de él. Por un lado, el tiempo que no se detiene hasta que llega el fin y de otro la circularidad, los ciclos vitales en su constante volver hasta que llega la muerte. De manera un tanto escatológica nos ilustra de este devenir, de esta huella que deja el paso del tiempo en el ser humano, este poema de Quevedo. Un producto kitsch que en esta ocasión le sirve al autor para abordar un complejo tema de carácter metafísico como es el tempus fugit una de las constantes preocupaciones del hombre de la época que los barrocos heredan de la cultura latina.

En otro orden de cosas, también podemos considerar como productos kitsch, esos poemas que como el poema 86 del RAE RM 6212, utilizan la repetición de un truco formal, de una rima forzada e incompleta con la que se invita al receptor a que juegue a imaginar y completarla. Un soneto en el que se sustituye la última sílaba de la palabra final del verso por una " $x$ ", una incógnita que cada uno rellena como quiere, en ese juego participativo del público que se presta a la interpretación erótica o escatológica, según el caso.

Cuando ella hizo primera, hice yo flux

y entonces trabajaba con mi box,

más quitese ya allá, señora, ox,

que huele ya mui mal su almoradux.

Yo me acuerdo cuando ella decía ax mas ya se traga entero el mayor pex y no hay quien de harta leña a su hornix. (Poema 86. RAE RM 6212)

Entreveladas alusiones a los órganos genitales de la dama y a su afición por los placeres sexuales y a la falta de higiene, que a buen seguro levantaban la risa fácil del 
espectador, en una fiesta privada o en un acto público, sobre un escenario. Existen varios ejemplos en este siglo del empleo de esta terminación en $-\mathrm{x}$, usada en poemas eróticos y festivos por autores como Góngora, o en poemas anónimos, como este recogido en el Cancionero sevillano de Lisboa:

Dungandux, dungandux, mozuelas con el dungandux.

Mozas si os queréis olgar con un dungandux que yo tengo, él es gordo y él es luengo, $\mathrm{y}$ en esto no hay que dudar; y si lo queréis provar veislo aquí, sacaldo a luz: dungandux, dungandux, mozuelas con el dungandux. (Labrador 2003, pág.53)

Otro producto kitsch dentro del amplio abanico de posibilidades que ofrecía la poética del siglo de Oro.

\section{Conclusióm}

Partiendo de la realidad de que en el siglo XVII existía una sociedad masiva que exigía cultura como producto de consumo; tomando como corpus explicativo el cancionero inédito RAE RM 6212, hemos conseguido constatar que muchos de los poemas que formaban parte de los cancioneros y volúmenes de poesías varias que circulaban durante el Barroco eran productos kitsch elaborados para satisfacer esa demanda. Unos productos creados casi siempre por artistas de segunda o tercera fila, pero en ocasiones también por autores prestigiosos de enorme talla intelectual que empleaban los resortes de la subcultura para llegar de una manera más eficaz a todo el abanico social. Escritores que en muchas ocasiones defendían en sus versos, si no de manera explícita sí implícita, una ideología, unas convicciones que estaban en el sustrato de un armazón poético de escasa calidad literaria . Un esqueleto formal que se apoyaba en la búsqueda de la risa fácil, usando para ello resortes casi infantiles como los juegos de palabras, las repeticiones, la imitación o el recurso a las insinuaciones sexuales o fisiológicas, a la escatología. Con todos esos ingredientes elaboraban un producto susceptible de interesar al gran público, de saciar sus expectativas lúdicas, y al mismo tiempo de transportar un mensaje con el que educar al receptor en un período, el siglo XVII, en el que era obligatorio enseñar deleitando. 


\section{Bibliografía}

ABRIL CURTO, Gonzalo (2003): Presunciones II. Ensayo sobre comunicación y cultura. Valladolid. Junta de Comunidades de Castilla y León.

ARREDONDO, M $\mathrm{M}^{\mathrm{a}}$ Soledad y otros (2009): Paratextos en la literatura española. Siglos XV-XVIII. Casa de Velázquez. Madrid.

BAJTIN, Mijail (1988): La cultura popular en la Edad Media y el Renacimiento. Barcelona. Daktal.

BATAILLON, Marcel (1979): Erasmo y España. México. Fondo de Cultura Económica.

DE CÓZAR, Rafael (1991): Poesía e imagen. Formas difíciles del ingenio literario. Sevilla. Carro de Nieve.

FERNÁNDEZ ÁLVAREZ, Manuel (2002). La sociedad española en el Siglo de Oro. Madrid. Gredos.

GARCÍA DE ENTERRÍA, M M Cruz (1973): Sociedad y poesía de cordel en el Barroco. Madrid. Taurus.

GIESZ, Ludwig (1960): Fenomenología del kitsch. Barcelona. Tuquets.

GRACIÁN, Baltasar (1974): Agudeza y arte de ingenio. Madrid. Espasa Calpe.

LABRADOR HERRAIZ, José Julián y DIFRANCO, Ralph (2003). Cancionero sevillano de Lisboa. Sevilla. Universidad de Sevilla.

(2008) Cancionero de Poesias varias. Ms. Reginensis Latini 1635 de la Biblioteca Vaticana. Universidad de Almería.

LAPESA, Rafael (1968): De la Edad Media a nuestros días. Madrid. Gredos

LIPMANN, Walter (1997): Public Opinion. New Cork. Free Press Paperlacks.

MARAVALL, José Antonio (1996): La cultura del Barroco. Barcelona. Ariel.

MONTORO, Antón de (1984): Poesía cancioneril. Barcelona. Plaza y Janés.

ORTEGA SIERRA, Sara (2010): Peleas de gayos en el cancionero de Baena: definición, tipología y poética del decir lúdico. University Lee.

PADILLA, Pedro de (2010): Cancionero de Pedro de Padilla con algunas obras de sus amigos. Edición de J. labrador y R. Di Franco. México. FAH.

PREGELJ, Bárbara (1999): El kitsch en el barroco castellano. Universidad de Ljubljana.

QUEVEDO, Francisco de (1981): Poesía original complete. Ed. J.M.Blecua. Barcelona. Planeta

RODRÍGUEZ DÍAZ, Raquel (2004): Teoría de la Agenda Setting. Aplicación a la enseñanza universitaria. Madrid. Observatorio Europeo de Tendencias Sociales.

ROGER DE LA FLOR, Fernando (2002): Barroco. Representación e ideología en el mundo hispánico (1580-1680). Madrid. Cátedra.

ROJAS, Fernando de (2004): La Celestina. Madrid. El País.

VALBUENA DE LA FUENTE, F. (2006): Eric Berne, teórico de la comunicación. Madrid. Edipo.

WARDROPPER W, Bruce (1958): Historia de la poesía lírica a lo divino en la cristiandad occidental. Madrid. Revista de Occidente.

WOODHOUSE, W (1978): Hacia una terminología coherente para la poesía satírica del siglo de Oro. Centro Virtual Cervantes. 